\title{
Complexation of diclofenac sodium with hydroxy propyl beta- cyclodextrin improves its solubility and stability in ampoule solution which is determined by HPLC
}

\section{Kahtan J.Hasson}

Al-Rasheed University College,department of Pharmacy,Baghdad,Iraq

\section{ABSTRACT}

Diclofenac sodium injection is widely used in medicine as antinflamatory and antirheumatic agent with a therapeutic value of $25 \mathrm{mg} / \mathrm{ml}$. However, diclofenac sodium is poorly soluble which forms a problem in its manufacturing as an injection.

The available commercial products of diclofenac sodium ampoules have used different types of solubilizing agents as benzyl alcohol which is an irritant in a concentration more than $3 \%$ while the other manufacturers used propylene glycol which has toxic impurities.

In this present work, Diclofenac Sodium injection is prepared by using Hydroxy Propyl Beta Cyclodextrine ; a natural and safe excipient in formulation of ampoule solution which formed an inclusion complex compounds with Diclofenac Sodium ,render it very soluble and more stable. The finished product of ampoules were subjected to the stability study by storing the samples at $40^{\circ} \mathrm{C}$ and $75 \% \mathrm{RH}$ for six months and the physico-chemical properties of the samples were tested at different periods. The results showed no change in appearance of the ampoules solution along the study time .In addition a reversed -phase high pressure liquid chromatographic method was developed and applied in studying the behavior of diclofenac Sodium in solution and its resistance to the high temperature challenger. The developed HPLC method was proved to be accurate and able to detect the degradation products of Diclofenac Sodium in solution.

Keywords: Diclofenac sodium, Hydroxy propyl beta-cyclodextrin (HPB-CD), inclusion complex, Chromatography HPLC.
*Correspondence to Author:

Kahtan J.Hasson

Al-Rasheed University College, department of Pharmacy,Bagh dad, Iraq.

How to cite this article:

Kahtan J. Hasson.Complexation of diclofenac sodium with hydroxy propyl beta-cyclodextrin improves its solubility and stability in ampoule solution which is determined by HPLC. Journal of Pharmaceutical Research and Reviews, 2018; 2:16.

\section{eScî̀Pub}

eSciPub LLC, Houston, TX USA. Website: http://escipub.com/ 


\section{Introduction:}

Preparation of Diclofenac sodium as a solution for injection faced a lot of manufacturing problems. Different solublizing agents have been used to solve the problem of the poor solubility character of diclofenac sodium ; such as addition of benzyl alcohol in a concentration not less than $7 \%$,this concentration render the solution in the ampoule to be irritant during intramuscular injection (I.M). On the other hand, the use of a co-solvent as propylene glycol to solubilize diclofenc sodium mostly contributed for the pain in the site of injection, [1]. Some workers have used other co-solvent with water as Transcutol solvent (Diethylene Glycol Monoethyl Ether ) to enhance the solubility of poor soluble substances including diclofenac sodium which need further safety studies, [2,3]. The recent development of beta-cyclodextrine (CD) and its derivative hydroxyl propyl betacyclodextrine (HPBCD) due to their safety nature because they are prepared from starch, the dramatic effect of CD and HPBCD substances as solubilizing character promoted their use in drug formulations, $\{4,5]$. Inclusion complex of cyclodextrin with different drugs formulation have proved good solubility and enhanced the dissolution of the solid dosage-forms $\{6,7\}$. Meanwhile, other workers reported that inclusion complexation of drugs with cyclodextrin derivatives as HPBCD has improved the stability of the active substance and its solubility in a rate relative to the concentrations of cyclodextrin in complex compound. $\{8,9\}$.

Obviously, the necessity to a specific method of analysis becomes clear to monitor the assay and to detect the expected changes in active substance during the stability study. The common UV spectrometric method for determination of diclofenac sodium is simple and accurate, however it lacks the specificity and cannot detect the presence of degradation products $[10\}$. Some HPLC methods for the determination of diclofenac sodium in dosage -forms as gel and injection [11 $\}$, and in biological macromolecules have been reported [12].

In this work, the complex compounding of diclofenac sodium with cyclodextrine ( HPBCD) was formulated as ampoules and a suitable stability- indicating method of HPLC was developed for diclofenac sodium in its inclusion complex with cyclodextrin.

\section{Materials and Method;}

Hydroxyl propyl beta cyclodextrin (HPBCD, trade mark Kleptose,Roquette Co.,.Diclofenac Sodium,Sodium metabisulfite,Benzyl alcohol, and propylene glycol (Al-Safa Co. for pharm.Ind., Iraq),HPLC apparatus(Cecile Co.),DSC-60 (schimadzo Co.,Japan),FTIR (China).

Preparation of diclofenac sodium injection using HPBCD;

To make $100 \mathrm{ml}$ solution of diclofenac sodium for injection which contains $2.5 \mathrm{gm}$ of diclofenac sodium (75 mg per $3 \mathrm{ml}$ ), disperse amount of diclofenac sodium in a portion of water with continuous stirring then pour it in a solution of HPBCD in water , mix and continue stirring at $70^{\circ} \mathrm{C}$ until clear solution. While stirring of the mixture add other ingredients as preservative and antioxidant, cool the solution to room temperature, adjust the $\mathrm{pH}$ between $(7-8)$ and complete to required volume with water, the final solution will be in a molar ratio of 1:1/2 of diclofenac sodium to HPB-CD. This preparation procedure is carried undercurrent of nitrogen gas through the solution, then filtered through membrane filter of $0.22 \mu$ pore size to fill sterile amber color ampoules with $3 \mathrm{ml}$ for each in a laminar flow followed by sealing. The proper sealing was checked and a part of these ampoules were undergo autoclaving.

The nature of the resulted complex of Diclofenac sodium with HPB-CD was studied, the soluble mixture in the ratio of $1: 1 / 2$ of Diclofenac sodium with HPB-CD was evaporated under vacuum and dried in an Oven, operated by hot air at $50^{\circ} \mathrm{C}$ for one hour. The dried and grinded solid residue of diclofenac sodium-HPB-CD 
complex was examined and clarified by IRspectrometry and DSC-scan

The assay of diclofenac sodium in the prepared ampoules was determined by using HPLC method which consists of the following conditions;

Column; C18,250mm x $4.5 \mathrm{~mm}$. The mobile phase was $30 \%$ acetonitrile in phosphate buffer $0.05 \mathrm{M}, \mathrm{pH} 5.0$, the injection volume of sample was $25 \mu \mathrm{L}$, and the peak of interest was detected by UV-detector at $254 \mathrm{~nm}$. This method was validated for precision, accuracy, specificity, reproducibility and its suitability for stability work. The solutions of Diclofenac sodium ampoules were prepared in different formulations and sterilized by micro filtration and other part with terminal autoclaving . the prepared ampoules were stored at the recommended conditions of stability work (at $30^{\circ} \mathrm{C} \& 65 \% \mathrm{RH}$ as a room temperature in Iraq, and at $40^{\circ} \mathrm{C} \& 75 \% \mathrm{RH}$ accelerated conditions). The physico- chemical properties of these ampoule solutions were examined at intervals during the period of storage.

Formulation of diclofenac sodium ampoule $75 \mathrm{mg} / 3 \mathrm{ml}$.

Generally,the amount of benzyl alcohol in new formula was replaced by HPB-CD as solubilizer; other stabilizing agents are the same.Methy paraben was used in $\mathrm{F} 3$, as it is reported to be used in a concentration (0.65 - $0.25 \%)$ parentrally $[13]$. All the solutions of different formulations of prepared ampoules contain 2.5 $\mathrm{gm}$ of Diclofenac sodium in $100 \mathrm{ml}$ solution, the composition of excipients in different formulations are mentioned in (table-1-).

\section{Table-1 compositions of different formulations of prepared diclofenac sodium ampoules}

\begin{tabular}{|l|l|l|l|l|}
\hline Formula & F1 & F2 & F3 & F4 \\
\hline $\begin{array}{l}\text { Sodium } \\
\text { metabisulfite }\end{array}$ & $0.1 \mathrm{gm}$ & $0.1 \mathrm{gm}$ & $0.1 \mathrm{gm}$ & -------- \\
\hline Benzyl alcohol & $17.5 \mathrm{ml}$ & ------- & --------- & -------- \\
\hline EDTA sodium & $0.05 \mathrm{gm}$ & $0.05 \mathrm{gm}$ & $0.05 \mathrm{gm}$ & $0.05 \mathrm{gm}$ \\
\hline HPB-CD & ------- & $5.5 \mathrm{gm}$ & $5.5 \mathrm{gm}$ & $5.5 \mathrm{gm}$ \\
\hline Methyl paraben & ------- & ------ & $0.07 \mathrm{gm}$ & $0.07 \mathrm{gm}$ \\
\hline
\end{tabular}

\section{Results and discussions;}

a-Infra-red examination:

The IR-spectrum of Diclofenac sodium (Fig-1-) show the characteristic peak at $3388 \mathrm{~cm}-1$ due to $\mathrm{NH}$ stretching of the secondary amine, 1569.2 $\mathrm{cm}-1$ of the $-\mathrm{C}=\mathrm{O}$ stretching of the carboxyl group and at $745 \mathrm{~cm}-1$ of $\mathrm{C}-\mathrm{Cl}$ stretching.

However, the broad and convex peak of HPB$\mathrm{CD}$ at the region $3300-3500 \mathrm{~cm}-1$ of the IRspectrum of HPB-CD (Fig-2-). caused by its $\mathrm{OH}$ group leads to the disappearance of the $\mathrm{NH}$ stretching peak of Diclofenac Sodium in the IRspectrum of the prepared complex mixture of Diclofenac Sodium and HPB-CD (Fig-3-), in addition there is no recorded new peak, indicating non-covalent interaction in the inclusion complex .

b-Differential scanning calorimetric test;

The DSC thermograph of diclofenac sodium powder show endothermic peak at $285{ }^{\circ} \mathrm{C}$ (Fig4-). However, the thermograph of the prepared Diclofenac sodium and HPB-CD complex powder show abroad peak of HPB-CD at about $92^{\circ} \mathrm{C}$ with a sign of shifting in the endothermic peak of Diclofenac sodium to about $256^{\circ} \mathrm{C}$, indicated the formation of inclusion complex (Fig-5-). 


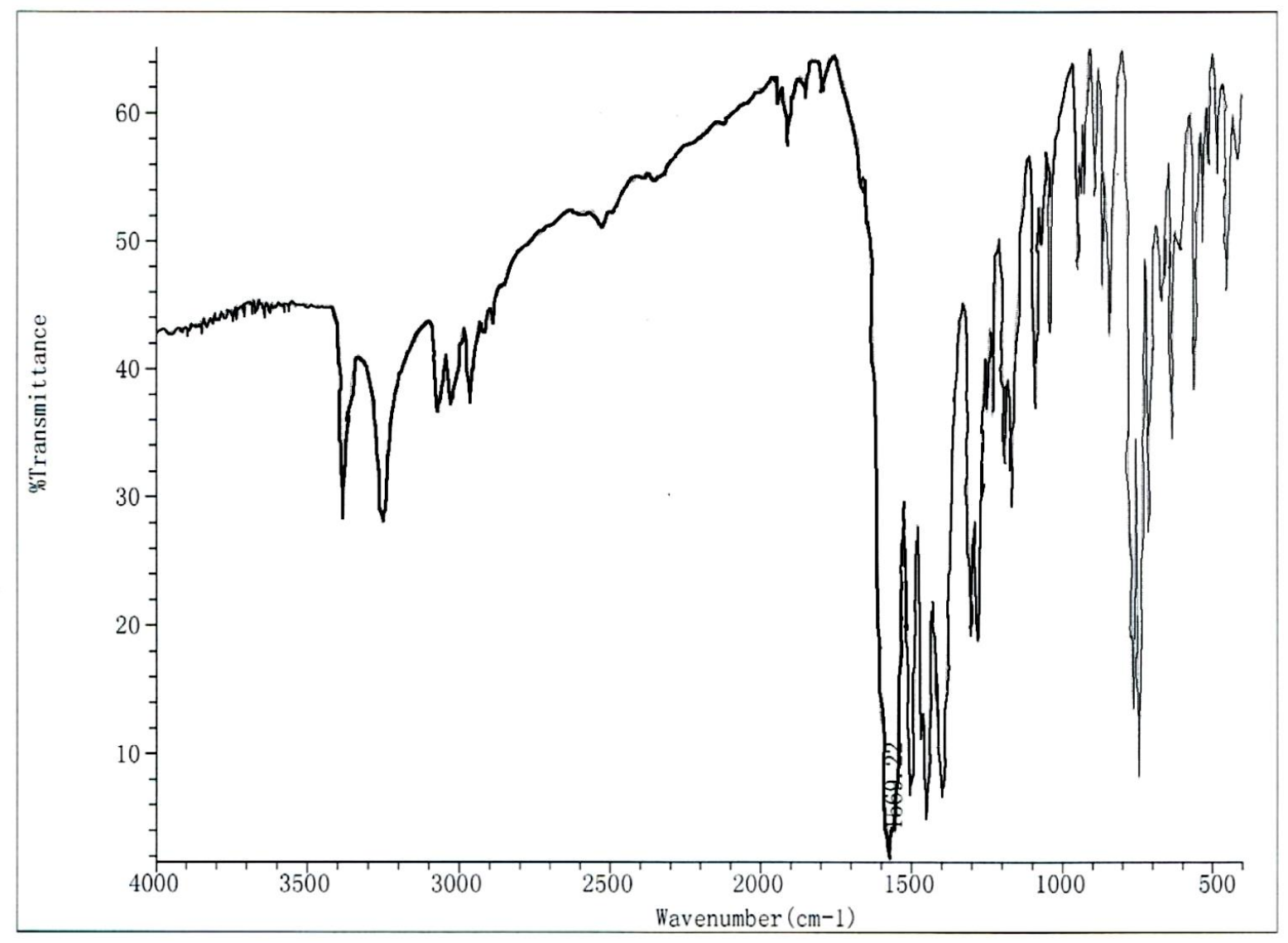

Figure-1- IR-spectrum of pure diclofenac sodium

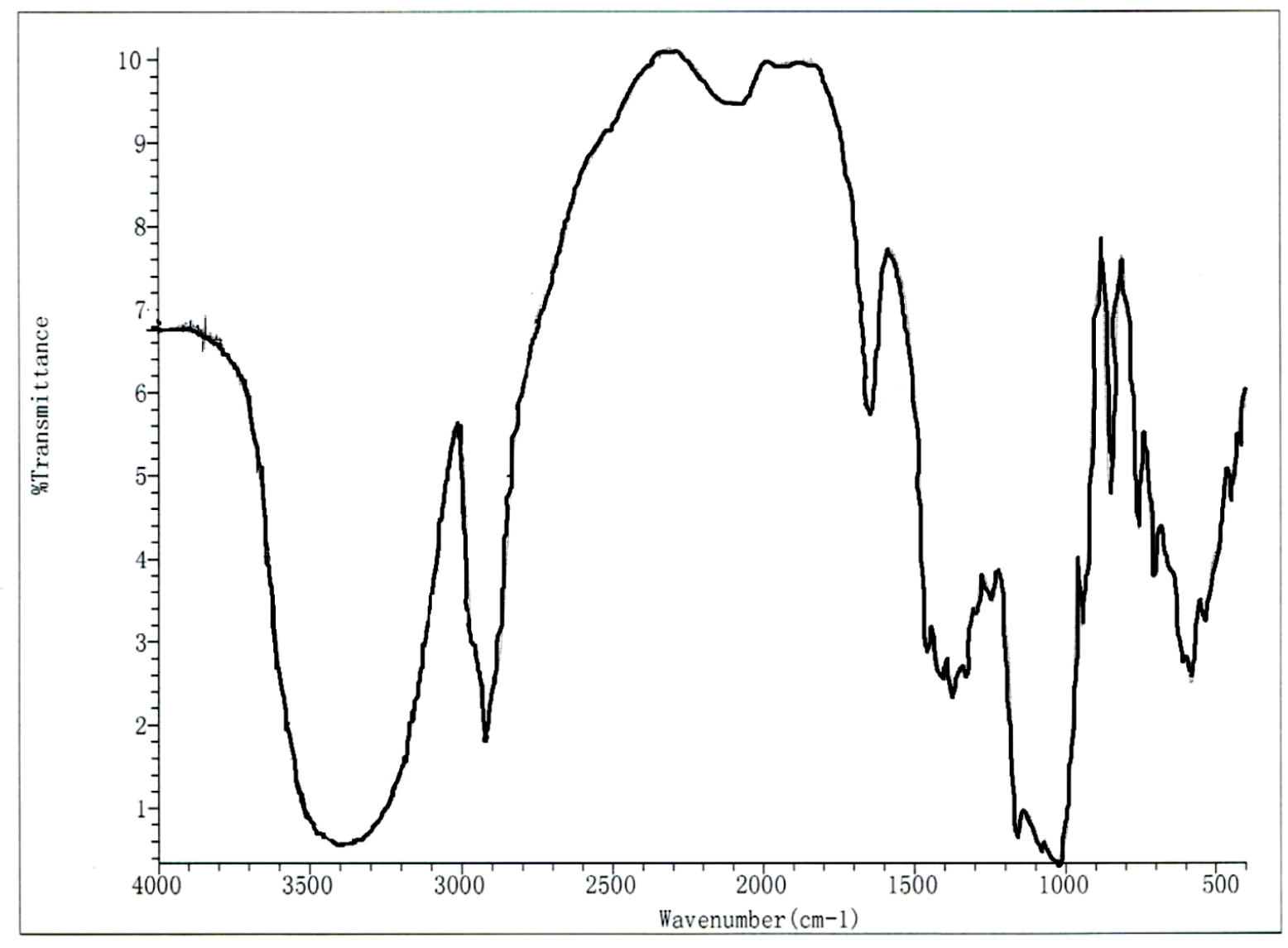

Figure-2- the IR-spectrum of HPB-CD 


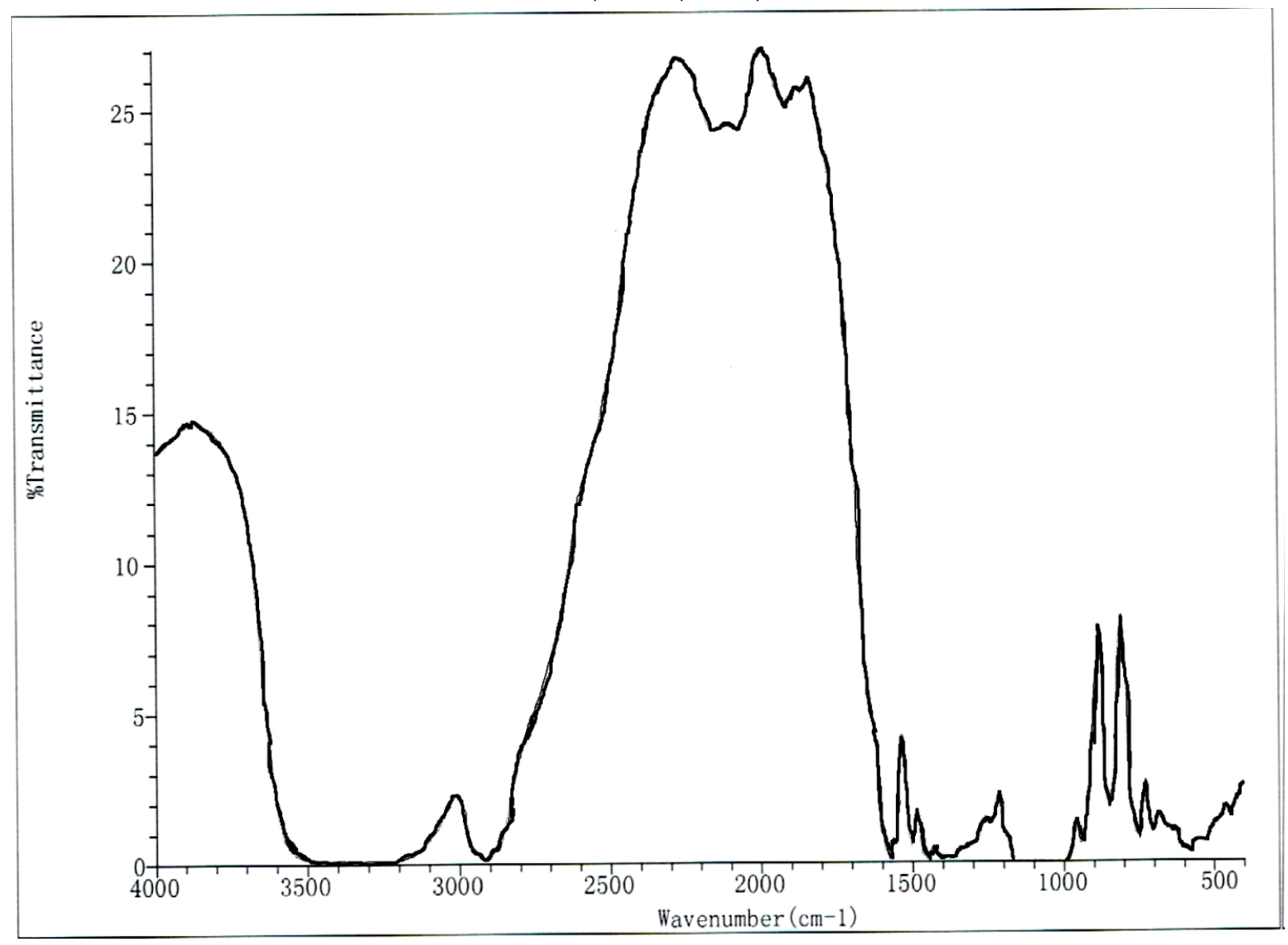

Figure-3- The IR-spectrum Diclofenad Sodium and HPB-CD complex.

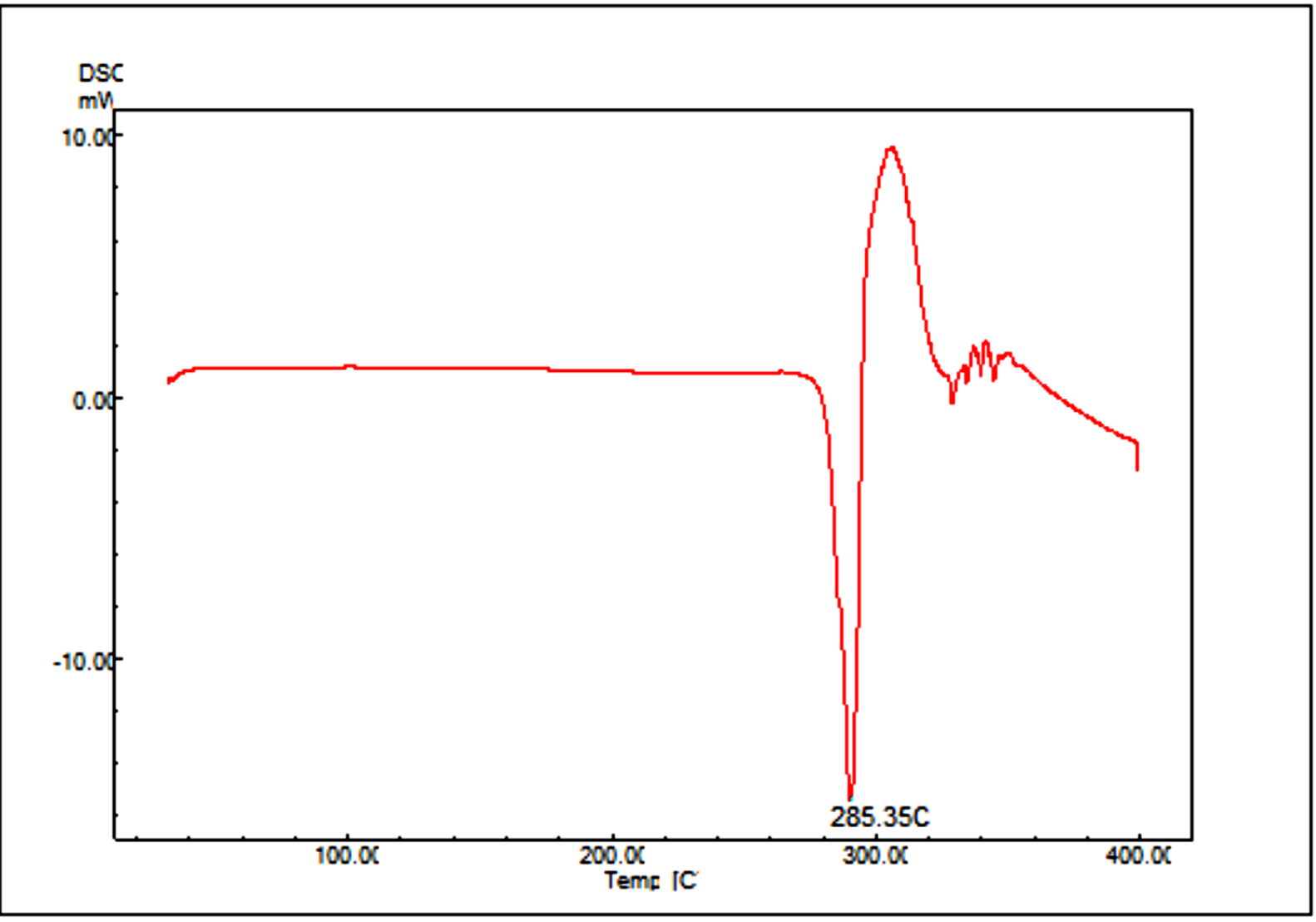

Figure-4-: the DSC thermograph of Diclofenac Sodium powder. 


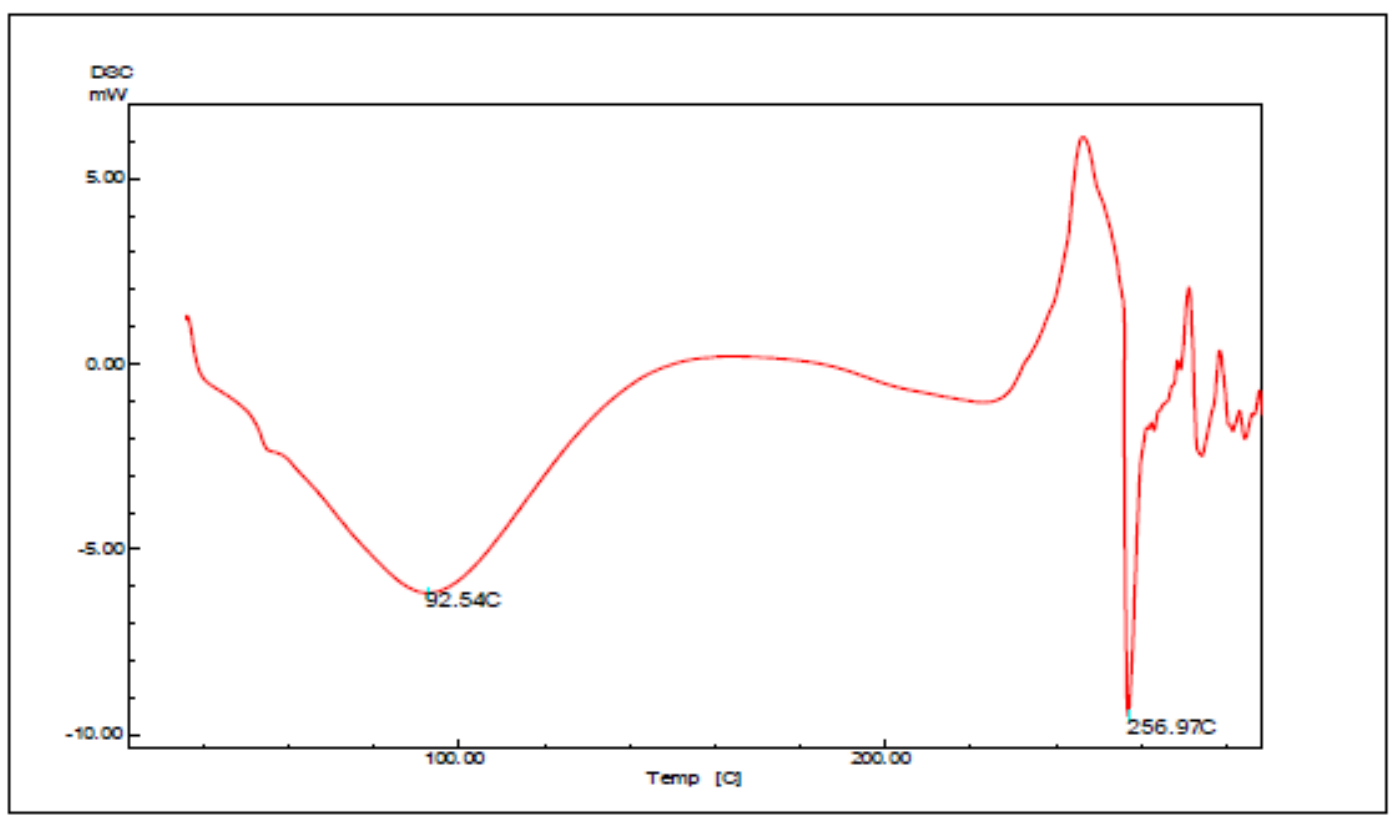

Figure-5- the DSC theromograph of Diclofenac sodium and HPB-CD complex

The HPLC analysis:

The HPLC-chromatogram of the prepared ampoule shows a peak for Diclofenac sodium of similar retention time with that of standard solution (Fig- 6-). The quantitative application of this method proved good precision; as the analysis of different dilutions in the range $(0.2-$ $1.2 \mathrm{mg} / \mathrm{ml}$ ) of diclofenac sodium exhibited a straight line relationship with the peak area of the resulted peaks (Fig-7-), the correlation coefficient was (0.999).Reproducibility test for five analytical applications shows a relative standard deviation (RSD 0.9\%). .Analysis of prepared sample of ampoule solution without Diclofenac sodium show no peak at the retention time of Diclofenac sodium peak, indicated the method specificity. The suitability of this method for stability work was studied; solution of Diclofenac sodium was subjected to heat at $70^{\circ} \mathrm{C}$ for one week, the solution become of deeply yellow color and its HPLC chromatogram show a secondary peak indicating occurrence of degradation (Fig-8-),

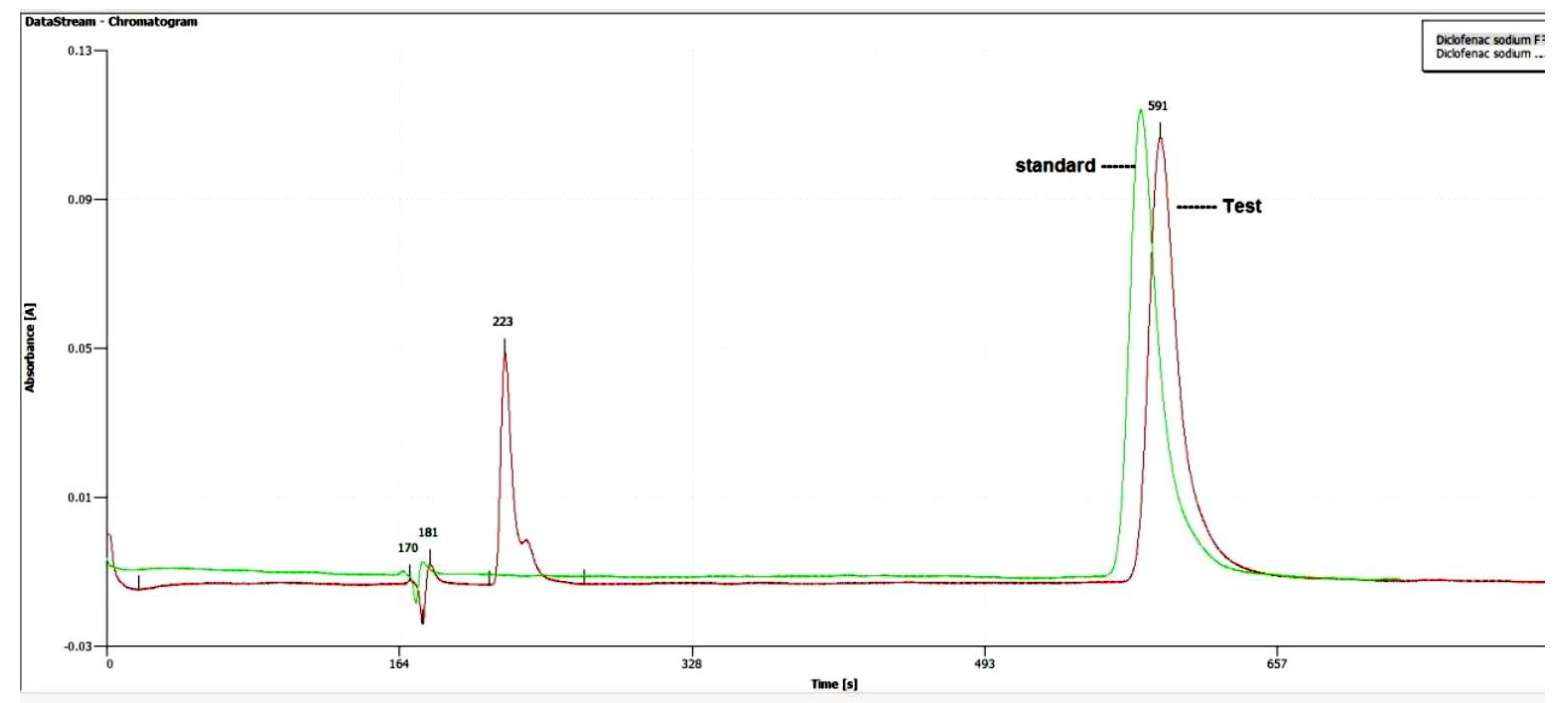

Figure-6- the peak of tested Diclofenac sodium ampoule appears at about 10 minutes and it was the same as standard solution. 


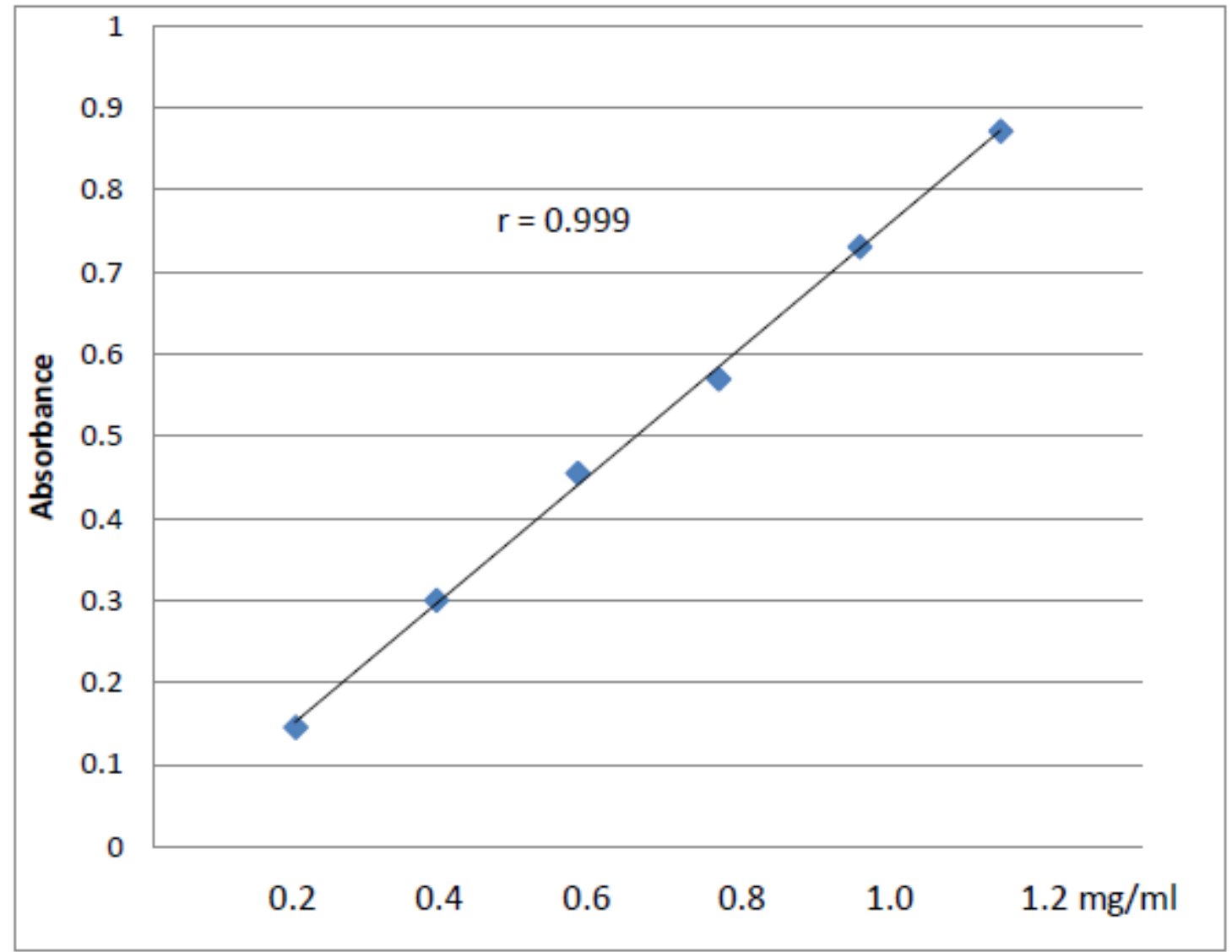

Figure-7- the straight-line relationship between peaks areas and concentrations of Diclofenac sodium.

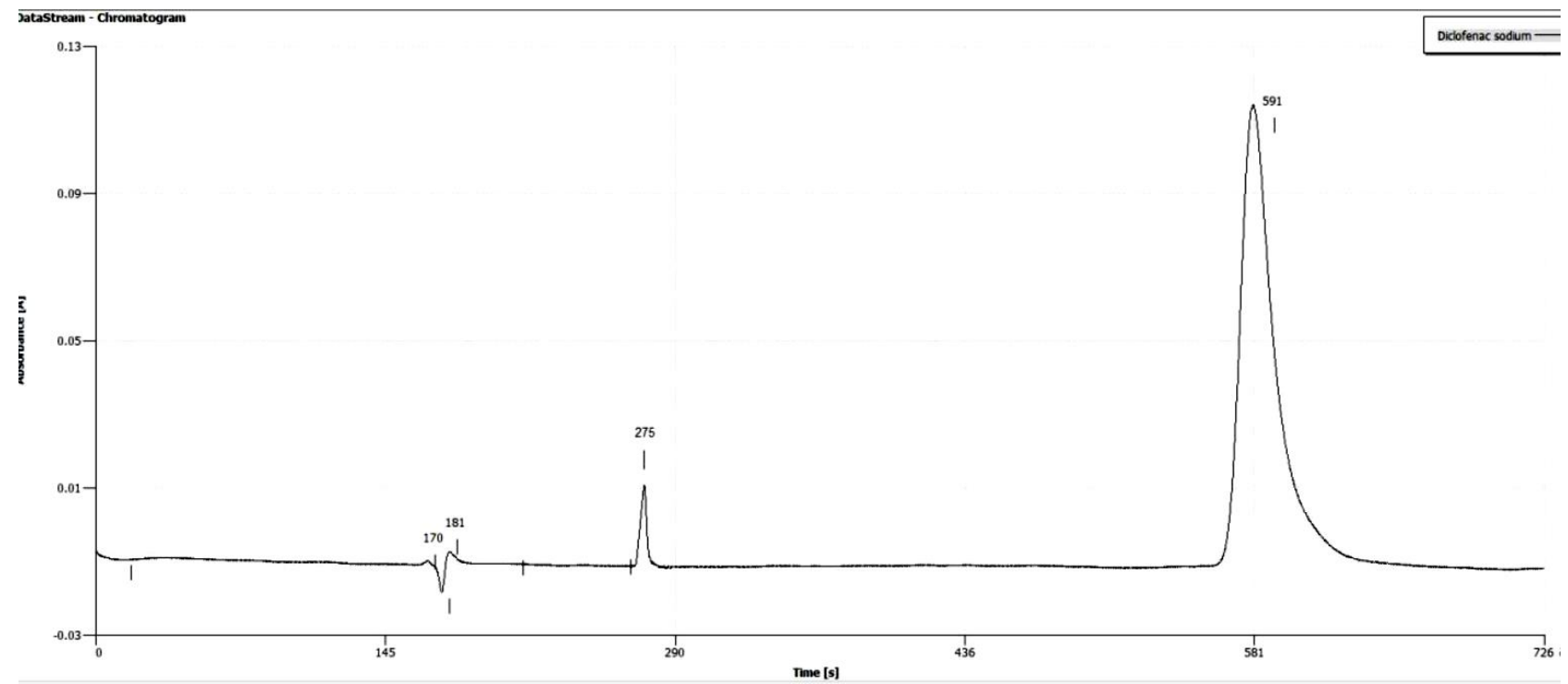

Figure-8- there is a detected secondary peak at 275 seconds (Rt), which indicates a sign of degradation.

Stability tests; the results of physico-chemical postulated in the following tables (table.-2-and changes in the prepared formulations of 3-). Samples of ampoules, sterilized by filtration diclofenac sodium ampoules due to storage at are referred as $(\mathrm{Fa})$ and those by terminal different conditions; included at room autoclaving as (Fb). temperature and accelerated conditions are 
Table-2- changes in the solutions of diclofenac sodium ampoules, of different formulations, stored at $25 \circ \mathrm{C} \& 65 \% \mathrm{RH}$.for one year.

\begin{tabular}{|l|l|l|l|l|l|}
\hline Formula & color & clarity & $\mathrm{pH}$ & $\begin{array}{l}\text { Assay of } \\
\text { Diclof.sod. }\end{array}$ & degradation \\
\hline F1a & $\begin{array}{l}\text { Slightly } \\
\text { yellow }\end{array}$ & $\begin{array}{l}\text { Few } \\
\text { particles }\end{array}$ & 7.8 & $99.2 \%$ & $\begin{array}{l}\text { Not } \\
\text { detected }\end{array}$ \\
\hline F2a & $\begin{array}{l}\text { Slightly } \\
\text { yellow }\end{array}$ & $\begin{array}{l}\text { Few } \\
\text { particles }\end{array}$ & 7.4 & $99.3 \%$ & $=$ \\
\hline F3a & colorless & clear & 7.8 & $100.1 \%$ & $=$ \\
\hline F4a & colorless & clear & 7.8 & $99.8 \%$ & $=$ \\
\hline F1b & yellow & $\begin{array}{l}\text { Few } \\
\text { particles }\end{array}$ & 7.4 & $97.0 \%$ & detected \\
\hline F2b & yellow & $\begin{array}{l}\text { Few } \\
\text { particles }\end{array}$ & 7.3 & $97.3 \%$ & detected \\
\hline F3b & $\begin{array}{l}\text { Slightly } \\
\text { yellow }\end{array}$ & clear & 7.6 & $98.8 \%$ & $\begin{array}{l}\text { Not } \\
\text { detected }\end{array}$ \\
\hline F4b & $\begin{array}{l}\text { Slightly } \\
\text { yellow }\end{array}$ & clear & 7.5 & $98.5 \%$ & $\begin{array}{l}\text { Not } \\
\text { deteced }\end{array}$ \\
\hline
\end{tabular}

Table-3- changes in the solutions of diclofenac sodium ampoules, of different formulations, stored at $40^{\circ} \mathrm{C} \& 75 \% \mathrm{RH}$. for one year.

\begin{tabular}{|l|l|l|l|l|l|}
\hline formula & color & clarity & $\mathrm{pH}$ & $\begin{array}{l}\text { Assay of } \\
\text { Diclof.sod. }\end{array}$ & degradation \\
\hline F1a & $\begin{array}{l}\text { Slightly } \\
\text { yellow }\end{array}$ & $\begin{array}{l}\text { Few } \\
\text { particles }\end{array}$ & 7.8 & $95.2 \%$ & detected \\
\hline F2a & $\begin{array}{l}\text { Slightly } \\
\text { yellow }\end{array}$ & $\begin{array}{l}\text { Few } \\
\text { particles }\end{array}$ & 7.4 & $96.3 \%$ & detected \\
\hline F3a & colorless & clear & 7.8 & $99.1 \%$ & $\begin{array}{l}\text { Not } \\
\text { detected }\end{array}$ \\
\hline F4a & colorless & clear & 7.8 & $99.8 \%$ & $\begin{array}{c}\text { Not } \\
\text { detected }\end{array}$ \\
\hline F1b & yellow & $\begin{array}{l}\text { Few } \\
\text { particles }\end{array}$ & 7.4 & $94.0 \%$ & detected \\
\hline F2b & yellow & $\begin{array}{l}\text { Few } \\
\text { particles }\end{array}$ & 7.3 & $92.3 \%$ & detected \\
\hline F3b & $\begin{array}{l}\text { Slightly } \\
\text { yellow }\end{array}$ & clear & 7.6 & $98.8 \%$ & $\begin{array}{l}\text { Not } \\
\text { detected }\end{array}$ \\
\hline F4b & $\begin{array}{l}\text { Slightly } \\
\text { yellow }\end{array}$ & clear & 7.5 & $98.5 \%$ & $\begin{array}{l}\text { Not } \\
\text { deteced }\end{array}$ \\
\hline
\end{tabular}

\section{Conclusion:}

This study indicates that the use of hydroxyl propyl beta-cyclodextrine enhances the solubility of diclofenac sodium in water for ampoule formulation, in addition it induces the stability of ampoule solution by formation of inclusion complex with the molecules of Diclofenac sodium and protects the drug against oxidation.

\section{Acknowledgment}

JPRR: http://escipub.com/journal-of-pharmaceutical-research-and-reviews/ 
I'd like to thank the group of Al-Safa company of pharmaceutical industry (Baghdad) for their support in supplying the chemicals during my experiments

\section{References;}

1. Martindale;The Complete Drug Reference, 36 Edition ,Edit. By Sean C Sweetman,Pharmaceutical Press, ,London,2009, Page 2374.

2. GA Shazly et al., Solution Thermodynamics and Solubility Prediction of Glibenclamide in Transcutol + Water Co-Solvent Mixtures at 298.15-333.15 K Arch Pharm Res 37 (6), 746-751. 2013 Dec 17.

3. GA Shazly et al., Solution Thermodynamics and Solubilization Behavior of Diclofenac Sodium in Binary Mixture of Transcutol-Hp and Water, Pha Pharmazie. 2014 May;69(5):335-9.

4. Scavone $C$ et al., Efficacy and Safety Profile of Diclofenac/Cyclodextrin and Progesterone/Cyclodextrin Formulations:A Review of the Literature Data. Drugs R D. 2016 Jun;16(2):129-40. doi: 10.1007/s40268-0160123-2

5. Leeson RM, Dyloject, a novel injectable diclofenac formulation, offers greater safety and efficacy than voltarol for postoperative dental pain. Reg Anesth Pain Med.,2007 Jul-Aug;32(4):30310.

6. Krunal Bhatt, et al., Formulation and Evaluation of Diclofenac Sodium Injection Using 2-Hydroxy Propyl Beta Cyclodextrin, International Journal of
Pharmacy and Pharmaceutical Sciences, Vol 3, Suppl 5, 2011

7. Saetern AM, et al,Effect of hydroxypropyl-betacyclodextrin-complexation and $\mathrm{pH}$ on solubility of camptothecin. . Int J Pharm. 2004 Oct 13;284(12):61-8-

8. Holvoet C, Inclusion complexation of lorazepam with different cyclodextrins suitable for parenteral use, Drug Dev Ind Pharm. 2005 Jul;31(6):567-75.

9. Holvoet C, Inclusion complexation of diazepam with different cyclodextrins in formulations for parenteral use. Pharmazie. 2005 Aug;60(8):598603.

10. Safila Naveed, Fatima Qamar, UV spectrophotometric assay of Diclofenac sodium available brands, Journal of Innovations in Pharmaceuticals and Biological Sciences, Vol 1 (3), 92-96, 2014

11. Lopamudra Adhikari,Search for simple mobile phases in rapid LC separation analysis of drugs in complex matrix diclofenac gel and injections International Journal of Pharmacy and Pharmaceutical Sciences, Vol 3, Issue 1, 2011,136-139.

12. Shiv SankarBhattacharyaa.et al., A RP-HPLC method for quantification of diclofenac sodium released from biological macromolecules, international journal of biological macromolecules, Volume 58, July 2013, Pages 354-359.

13. Handbook of Pharmaceutical Excipients, Raymond C Rowe, Paul J Sheskey, Marian E Quinn ; Pharmaceutical Press and American Pharmacists Association,6th edition,2009,p 444

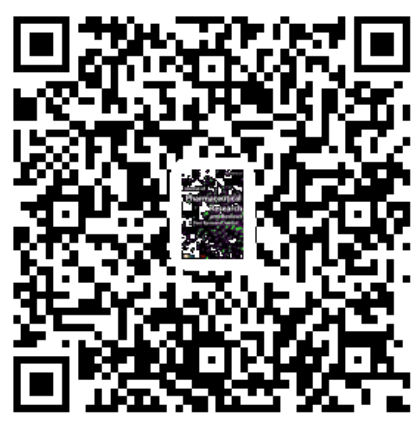

